ПРЕВАЛЕНЦИЈА ПУШЕЊА И ЕПИДЕМИОЛОГИЈА РАКА ПЛУЋА И ДУШНИКА У РЕПУБЛИЦИ СРПСКОЈ

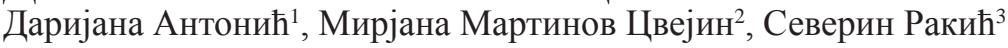

\title{
SMOKING PREVALENCE AND CANCER EPIDEMIOLOGY OF THE LUNG AND BRONCHUS IN REPUBLIC OF SRPSKA
}

Darijana Antonić, Mirjana Martinov Cvejin, Severin Rakić

\section{Сажетак}

Увод: У Републици Српској, ентитету Босне и Херчеговине, рак плућа и душника представља водећи јавноздравствени проблем. Сваке године региструје се око 700 нових случајева, а од укупног броја умрлих од рака, од рака плућа и душника умре свака четврта особа. Настанак рака плућа и душника доводи се у директну везу са пушењем, а према резултатима истраживања свакодневно и повремено пуши око 1/3 одраслог становништва Републике Српске.

Материјал и методе рада: У овом раду су коришћени подащи Регистра малигних неоплазми Републике Српске, показатељи везани за преваленцију пушења из извјештаја о резултатима истражсивања ,Истражсивање здравља становништва Републике Српске”, као и подаци из базе малигних неоплазми GLOBOCAN 2008, Међународне агенције за истражсивање рака (IARC).

Резултати рада: У Републици Српској рак плућа и душника код оба пола има веома високу инциденцију и морталитет, али веома ниску преваленцију. Око 70\% новооткривених и умрлих случајева рака плућа и душника је у добној скупини 50-74 године живота. Највећи број сталних пушача је у добној скупини 35-44 године живота, а просјечна дужина пушачког стажаје око 20 година. Рак плућа и душника је више заступьен међу мушкарцима, као и навика пушења. Укупна релативна петогодишьа стопа преживљавана за оба пола је око $15 \%$.

\section{Summary}

Introduction: Cancer of the lung and bronchus is leading public health issue in the Republic of Srpska, Entity of Bosnia and Herzegovina. Each year the number of new cases of cancer of the lung and bronchus is approximately 700 and from of all cancer deaths one in four persons died from cancer of lung and bronchus. Leading cause of its cancers is smoking and according to results of research $1 / 3$ of adult population smoking daily and occasional in the Republic Srpska.

Sources and methods: In this paper was used database Cancer Registry of Republic of Srpska, indicators related to smoking prevalence from the report of the results of the research „Researching Population Health's in the Republic of Srpska" and cancer database GLOBOCAN 2008, International Agency for Research on Cancer.

Results: In the Republic of Srpska cancer of the lung and bronchus both sex have very high incidence and mortality but very low prevalence. About 70\% new and death cases are in ages 50-74 years. The most daily smokers are in ages 35-44 years, average duration of smoking is approximately 20 years. Cancer of the lung and bronchus is common among men as a smoking habit. The 5-year relative survival rate both sex is about $15 \%$.

Key words: cancer of the lung and bronchus, incidence, mortality, prevalence, smoking.

\footnotetext{
${ }^{1}$ Мр сц. Даријана Антонић, Центар за здравствени менаџмент, ЈЗУ Институт за јавно здравство, Република Српска, Бања Лука.

2 Проф. др Мирјана Мартинов Цвејин, Фармацеутски факултет Нови Сад, Универзитет Привредна академија у Новом Саду.

${ }^{3}$ Проф. др Северин Ракић, Центар за здравствени менаџмент, ЈЗУ Институт за јавно здравство, Република Српска, Бања Лука.
} 
Кључне ријечи: рак плућа и душника, инцииденција, морталитет, преваленција, пушење.

\section{УВОД}

$\mathrm{P}$ ак плућа и душника је најчешћи рак у свијету код мушкараца, чија инциденција има стални тренд раста. Ова малигна неоплазма се од 30их година прошлог вијека (XX вијека) налази међу пет водећих узрока обољевања становништва свијета, а од 80-их година (XX вијека) заузима водећу позицију у обољевању од рака. ${ }^{(1)}$

У свијету од укупног броја новооткривених случајева рака плућа и душника (1,6 милиона), више од половине или 55\% новооткривених случајева је у земљама у развоју, са највећом заступљеношћу овог рака у региону источне Азије (Кина) и јужне/централне Азије (Индија). ${ }^{(2)}$ У развијеним регионима свијета највећи број новооткривених случајева овог рака је у региону Сјеверне Америке, свим регионима Европе и региону источне Азије (Јапан). ${ }^{(2)}$

У погледу морталитета, рак плућа и душника у свијету, и код мушкара и жена, заузима другу позицију (око 1,4 милиона), док у земљама у развоју рак плућа и душника се налази на првом мјесту. Највећи број умрлих од рака плућа и душника је у Кини. ${ }^{(2)}$ Пад у броју умрлих од овог рака у развијеним земљама свијета је настао као посљедица пада (од 90-их година) преваленције пушења у овим земљама. ${ }^{(3)}$

Пушење, као најважнији фактор ризика се у $90 \%$ случајева доводи у везу са раком плућа и душника. ${ }^{(4)}$ Проучавање епидемиолошких показатеља (инциденције и морталитета) рака плућа и душника указују на различите фазе епидемије пушења унутар једне земље. ${ }^{(5)}$

У Републици Српској, у периоду 20042008. године, рак плућа и душника с учешћем од $80 \%$ у инциденцији представља водећу локализацију малигне неоплазме на органима за дисање. Код мушкараца рак плућа и душника у инциденцији заузима водећу позицију с учешћем од $24 \%$, док код жена заузима четврту позицију с учешћем од око 6\%. Исто тако, у укупном морталитету од малигних неоплазми, рак плућа и душника представља водећи узрок умирања. Посматрано према полу, рак плућа и душника представља водећи узрок умирања мушкараца с учешћем од око $30 \%$, и други је (иза рака дојке) водећи узрок умирања жена с учешћем од око $11 \%$.

Према истраживању Министарста здравља и социјалне заштите Републике Српске које је спроведно 2010. године, у Републици Српској око $1 / 3$, или $31,0 \%$, одраслих становника свакодневно или повремено пуши (преваленција пушења), од чега је ова навика више заступљена међу мушкарцима. ${ }^{(6)}$

Стога је Влада Републике Српске донијела значајан број стратешких докумената, а у примјени је и значајан број прописа који имају зациљ смањење бројапушача, односно смањење преваленције пушења. Такође, Парламент Босне и Херцеговине (2009. године) је донијео Одлуку о ратификацији Оквирне конвенције Свјетске здравствене организације о контроли дувана. ${ }^{(7)}$ Исто тако, значајна је улога тимова породичне медицине у спровођењу мјера за откривање и сузбијање фактора ризика (пушења), као примарној превенцији овог фактора ризика.

И поред значајних мјера и активности које су предузете како би се смањила преваленција пушења у Републици Српској, стопе инциденције и морталитета рака плућа и душника код мушкараца показују тренд раста, док су код жена ове стопе у паду. 


\section{МАТЕРИЈАЛ И МЕТОДЕ РАДА}

У овом раду коришћени су подаци из Регистра малигних неоплазми Републике Српске о новообољелим и умрлим од рака плућа и душника у периоду 2004-2008. године. ${ }^{(8)}$ Подаци о обољелим од малигних неоплазми у Регистру се прикупљају по јединственој методологији из свих јавних и приватних здравствених установа, док се подаци о умрлим од малигних неоплазми прикупљају на основу података из Статистичког листића о случају смрти (чији је саставни дио и потврда о смрти). Потврде о смрти се достављају ЈЗУ Институту за јавно здравство, Бања Лука на контролу и шифрирање узрока смрти, док статистичку обраду података из потврда врши Републички завод за статистику Републике Српске.

Старосно стандардизоване стопе инциденције, морталитета и преваленције (на 100.000 особа) израчунате су методом директне стандардизације. За израчунавање старосно стандардизованих стопа (инциденције, морталитета и превеленције, на 100.000 особа) кориштена је стандардна свјетска популација по Segiu 1960, а коју cy Doll и др. модификовали 1966. године и стандардна популација Републике Српске. ${ }^{(9)}$

Истраживање потенцијално изгубљених година живота (PLLY) обухватило је све случајеве рака плућа и душника који су умрли прије 75. године живота, док су при истраживању кумулативног ризика оболијевања и умирања од рака плућа и душника, кориштене граничне старости прије 65. и прије 75. године живота.

За израчунавање релативних стопа преживљавања (једногодишњих и петогодишњих) укључени су сви новооткривени случајеви рака плућа и душника који су откривени у периоду 2004-2008. године, а чији витални статус је праћен до краја 2009. године (31. 12. 2009. године). Случајеви рака плућа и душника који су у посматраном периоду умрли од неког другог узрока смрти искључени су из израчунавања релативних стопа преживљавања.

Варијабле које су кориштене за израчунавање ових стопа су: старост, пол, датум утврђивања рака плућа и душника, крајњи датум који је одабран за праћење преживљавања (у овом случају 31. 12. 2009.) и витални статус на крају посматраног периода за сваки случај обољелог од рака плућа и душника. Такође, израчунат је интервал поузданости релативних стопа преживљавања (једногодишњих и петогодишњих) за ниво статистичке значајности $95 \%$.

У раду су кориштене процјене нововоткривених и умрлих случајева, као и процјене стопа инциденције и морталитета рака плућа и душника у свијету за 2002. и 2008. годину из базе GLOBOCAN 2002. и 2008, Међународне агенције за истраживање рака (IARC). ${ }^{(2,10)}$

У раду су кориштенипоказатељи везаниза превеленцију пушења у Републици Српској из Извјештаја о резултатима истраживања здравља становништва Републике Српске које је 2010. године, спровео Ј3У Институт за јавно здравство, Бања Лука, Република Српска, са регионалним центрима Добој, Источно Сарајево, Фоча, Требиње и Зворник. ${ }^{(6)}$

\section{РЕЗУЛТАТИ РАДА}

У Републици Српској у просјеку се годишње региструје око 700 новооткривених случајева рака плућа и душника код мушкараца, а у просјеку годишње умре око 600 мушкараца. Рак плућа и душника се у просјеку открије код око 130 жена, док у просјеку годишње умре око 100 жена. Код оба пола однос између инциденције и морталитета од рака плућа и душника износи 1,2:1 (Табела 1).

Од рака плућа и душника највише оболијева и умире становништво које припада добним скупинама од 50-64 и 65-74 године (око 70\%) (Графикон 2). 
Медијана старости оболијевања и умирања од рака плућа и душника код оба пола је око 70 година живота (Табела 2).

Мушкарци у односу на жене имају око 5 пута већи ризик да оболе од рака плућа и душника (прије 65. и прије 75. године живота), док су у погледу умирања од ове локализације рака, око 2 пута (прије 65. године), односно око 3 пута (прије 75. године) под већим ризиком (Табела 2).
У односу на жене, мушкарци се у периоду 2004-2008. године, због пријевременог умирања (прије 75. године живота) од рака плућа и душника имали 5 пута већи потенцијални губитак година живота. Иако постоје значајне разлике у потенцијалном губитку година живота између мушкараца и жена, оба пола су због пријевремене смрти у просјеку изгубила око 12 година живота (Табела 2).

Табела 1. Инциденција и морталитет свих локализащија рака (С00-96) и рака плућа и душника (С33-34) у Републици Српској, оба пола, 2004-2008.

\begin{tabular}{|c|c|c|c|c|c|c|c|c|c|c|}
\hline \multirow{2}{*}{$\begin{array}{l}\text { Ред. } \\
\text { број }\end{array}$} & \multirow[b]{2}{*}{ Пол } & \multirow[b]{2}{*}{ Локализација } & \multicolumn{5}{|c|}{ Година } & \multirow[b]{2}{*}{ Укупно } & \multirow[b]{2}{*}{$\%$} & \multirow{2}{*}{$\begin{array}{c}\text { Просјечан } \\
\text { број } \\
2004-08\end{array}$} \\
\hline & & & 2004 & 2005 & 2006 & 2007 & 2008 & & & \\
\hline 0 & 1 & 2 & 3 & 4 & 5 & 6 & 7 & 8 & 9 & 10 \\
\hline 1 & Мушкарци & & & & & & & & & \\
\hline 2 & & Све локализације & 2333 & 2307 & 2337 & 2667 & 2666 & 12310 & 100 & 2462 \\
\hline 3 & Инциденщија & Плућа и душник & 564 & 559 & 567 & 600 & 610 & 2900 & 23,56 & 580 \\
\hline 4 & & Све локализације & 1483 & 1614 & 1501 & 1605 & 1671 & 7874 & 100 & 1575 \\
\hline 5 & Морталитет & Плућа и душник & 476 & 495 & 486 & 514 & 545 & 2516 & 31,95 & 503 \\
\hline 6 & Жене & & & & & & & & & \\
\hline 7 & $U$ & Све локализације & 1967 & 1939 & 1997 & 2195 & 2267 & 10365 & 100 & 2073 \\
\hline 8 & Инциденција & Плућа и душник & 166 & 132 & 127 & 125 & 122 & 672 & 6,48 & 134 \\
\hline 9 & Морталитет & Све локализације & 1016 & 1066 & 1008 & 1095 & 1062 & 5247 & 100 & 1049 \\
\hline 10 & & Плућа и душник & 141 & 119 & 108 & 101 & 104 & 573 & 10,92 & 115 \\
\hline
\end{tabular}

У петогодишњем периоду посматрања (2004-2008. године), у Републици Српској просјечна старосно стандардизована стопа инциденције (становништво Републике Српске) рака плућа и душника код мушкараца износила је 88,8/100.000, а морталитета 77,3 /100.000 мушкараца. За разлику од мушкараца, жене су имале око 5 пута нижу просјечну старосно стандардизовану стопу инциденције $(17,1$ на 100.000 жена) и морталитета (14,4 на 100.000 жена).
Стопе инциденције и морталитета рака плућа и душника код мушкараца су у 2008. у односу на 2004. годину имале просјечан годишњи раст од 2,2\%. У истом периоду стопе инциденције код жена имале су просјечан годишњи пад од $8,5 \%$, односно морталитета од 9,2\%. Вриједности петогодишње стопе преваленције рака плућа и душника код мушкараца (85,3/100 000) и код жена $(16,9 / 100000)$ су готово изједначене са релевантним стопама морталитета. (Графикон 1). 
Графикон 1. Старосно стандардитована стопа (Република Српска) инциденције, морталитета и петогодишње превалнение (до краја 2008.) на 100.000 становника, рака плућа и душника, према полу, Република Српска, 2004-2008.

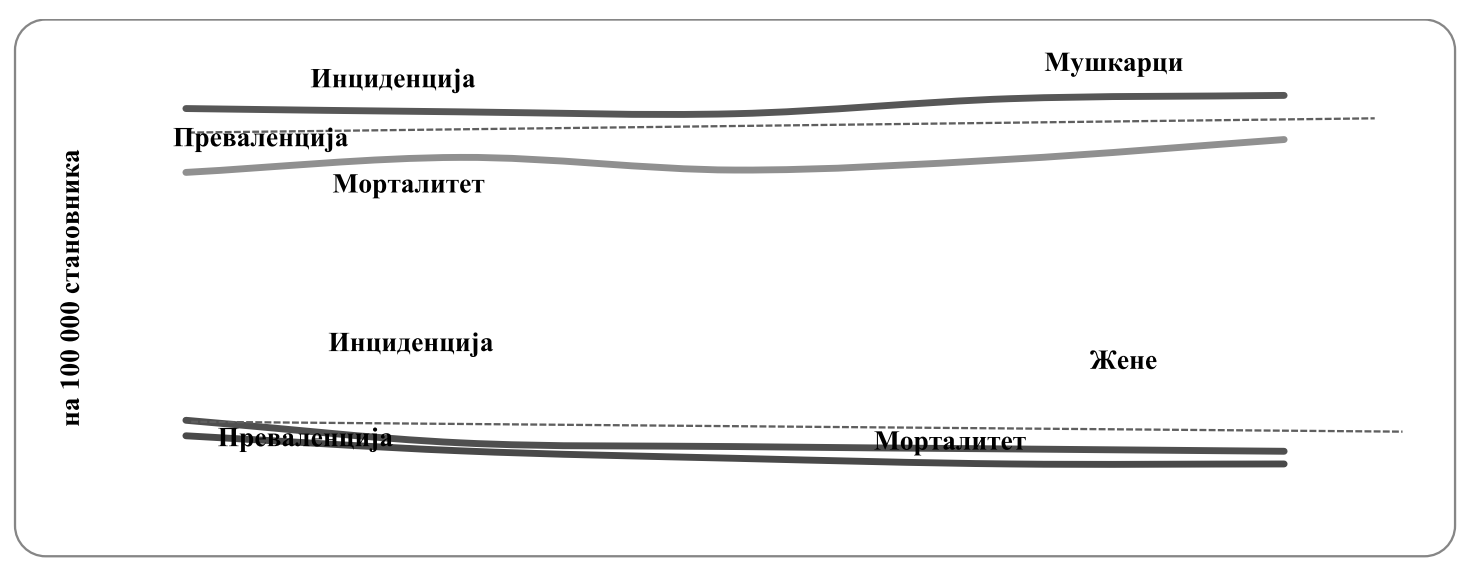

Старосно стандардизоване стопе инциденције и морталитета рака плућа и душника код мушкараца у Републици Српској су нешто више у односу на просјечне стопе овог рака код мушкараца у свијету (GLOBOCAN, 2002. и 2008). Насупрот томе, жене у Републици Српској имају ниже старосно стандардизоване стопе инциденције и морталитета у односу на просјечне старосно стандардизоване стопе оболијевања и умирања жена од овог рака у свијету (Табела 3).

Табела 2. Медијана старости, кумулативни ризик (прије 65. и 75. године живота) облијеваға умирања од рака плућа и потенцијално изгубљене године жсивота (PYLL) прије 75. године живота, према полу, Република Српска, 2004-2008.

\begin{tabular}{|c|c|c|c|c|c|c|c|c|c|c|c|c|}
\hline \multirow{3}{*}{$\begin{array}{l}\text { Ред. } \\
\text { број }\end{array}$} & \multirow{3}{*}{ Пол } & \multicolumn{5}{|c|}{ Оболијевање } & \multicolumn{5}{|c|}{ Умирање } & \multirow{3}{*}{$\begin{array}{c}\text { Укупно } \\
\text { PYLL/ } \\
\text { Просјек } \\
\text { изгубљених } \\
\text { година }\end{array}$} \\
\hline & & \multirow[t]{2}{*}{$\begin{array}{c}\text { Медијана } \\
\text { старости } \\
\text { (године) }\end{array}$} & \multicolumn{2}{|c|}{$\begin{array}{c}\text { Кумулативни } \\
\text { ризик } \\
\text { 0-64 године }\end{array}$} & \multicolumn{2}{|c|}{$\begin{array}{c}\text { Кумулативни } \\
\text { ризик } \\
0-74 \text { године }\end{array}$} & \multirow[t]{2}{*}{$\begin{array}{l}\text { Медијана } \\
\text { старости } \\
\text { (године) }\end{array}$} & \multicolumn{2}{|c|}{$\begin{array}{c}\text { Кумулативни } \\
\text { ризик до } \\
\text { 0-64 године }\end{array}$} & \multicolumn{2}{|c|}{$\begin{array}{c}\text { Кумулативн } \\
\text { и ризик до } \\
0-74 \text { године }\end{array}$} & \\
\hline & & & $\%$ & 1 од & $\%$ & 1 од & & $\%$ & 1 од & $\%$ & 1 од & \\
\hline 0 & 1 & 2 & 3 & 4 & 5 & 6 & 7 & 8 & 9 & 10 & 11 & 12 \\
\hline 1 & Мушкарци & 67 & 2,7 & 37 & 5,7 & 18 & 68 & 2,1 & 48 & 4,9 & 20 & $\begin{array}{c}23837,5 / \\
12 \text { година }\end{array}$ \\
\hline 2 & Жене & 68 & 0,5 & 200 & 1,1 & 91 & 69 & 0,9 & 111 & 1,5 & 67 & $\begin{array}{l}4990,0 / \\
12 \text { година }\end{array}$ \\
\hline
\end{tabular}

Табела 3. Старосно стандардизована (свијет) стопа инцидениије и морталитета на 100.000 становника рака плућа и душника, према полу, у Републици Српској и свијету у 2002. и 2008. години.

\begin{tabular}{|c|c|c|c|c|c|c|c|c|c|}
\hline \multirow{3}{*}{$\begin{array}{l}\text { Ред. } \\
\text { бро } \\
\text { j }\end{array}$} & \multirow{3}{*}{ Пол } & \multicolumn{4}{|c|}{ Република Српска } & \multicolumn{4}{|c|}{ Свијет* } \\
\hline & & \multicolumn{2}{|c|}{ Инциденција } & \multicolumn{2}{|c|}{ Морталитет } & \multicolumn{2}{|c|}{ Инциденција } & \multicolumn{2}{|c|}{ Морталитет } \\
\hline & & 2002 & 2008 & 2002 & 2008 & 2002 & 2008 & 2002 & 2008 \\
\hline 0 & 1 & 2 & 3 & 4 & 5 & 6 & 7 & 8 & 9 \\
\hline 1 & Мушкарци & 45,8 & 46,0 & 31,5 & 40,7 & 35,5 & 34,0 & 31,2 & 29,3 \\
\hline 2 & Жене & 10,9 & 8,0 & 7,4 & 6,7 & 12,1 & 13,6 & 10,3 & 11,0 \\
\hline
\end{tabular}

*Извор: GLOBOCAN, 2002. ${ }^{(10)}$ и $2008^{(2)}$ 
Графикон 2. Учешће оболијевања и умирања од рака плућа према добним скупинама, оба пола, Република Српска, 2004-2008.

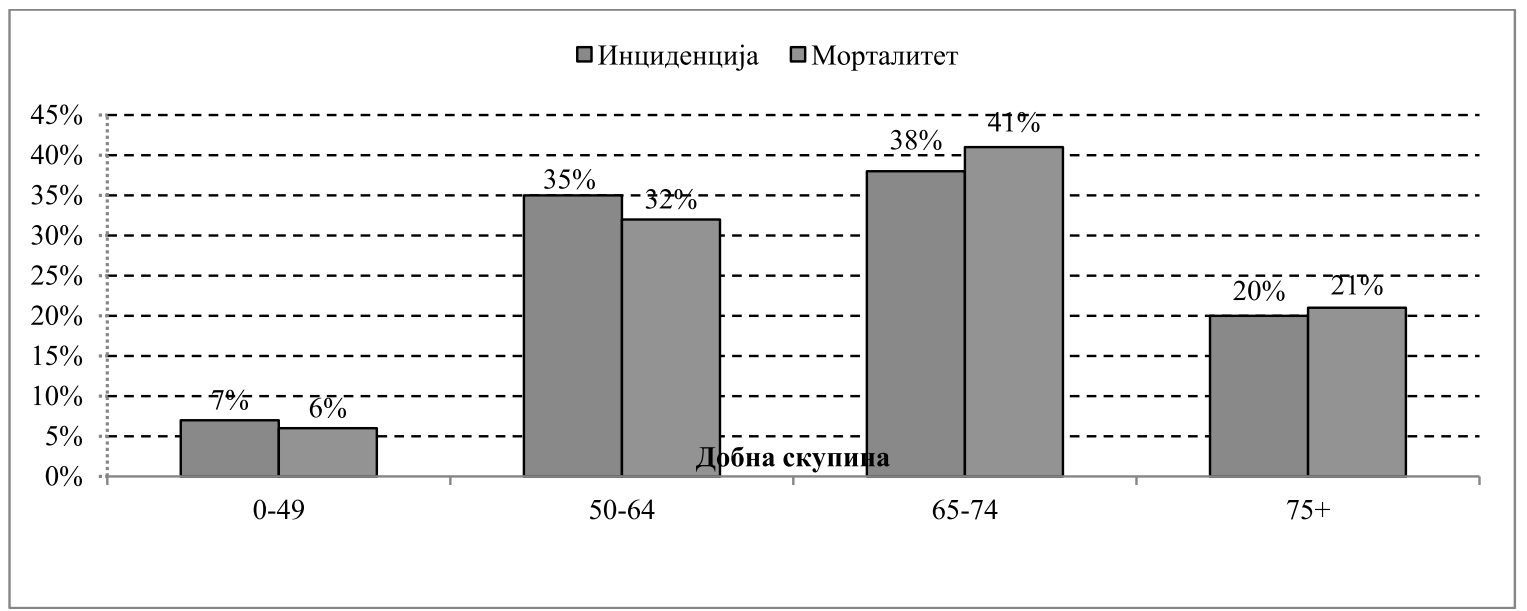

Графикон 3. Укупна релативна једногодишьа и петогодишња стопа преживљавања (\%) и релативна петогодишь а стопа прежсиљавања (\%) у одабраним добним скупинама водећих локализачија малигних неоплазми, оба пола, Република Српска.

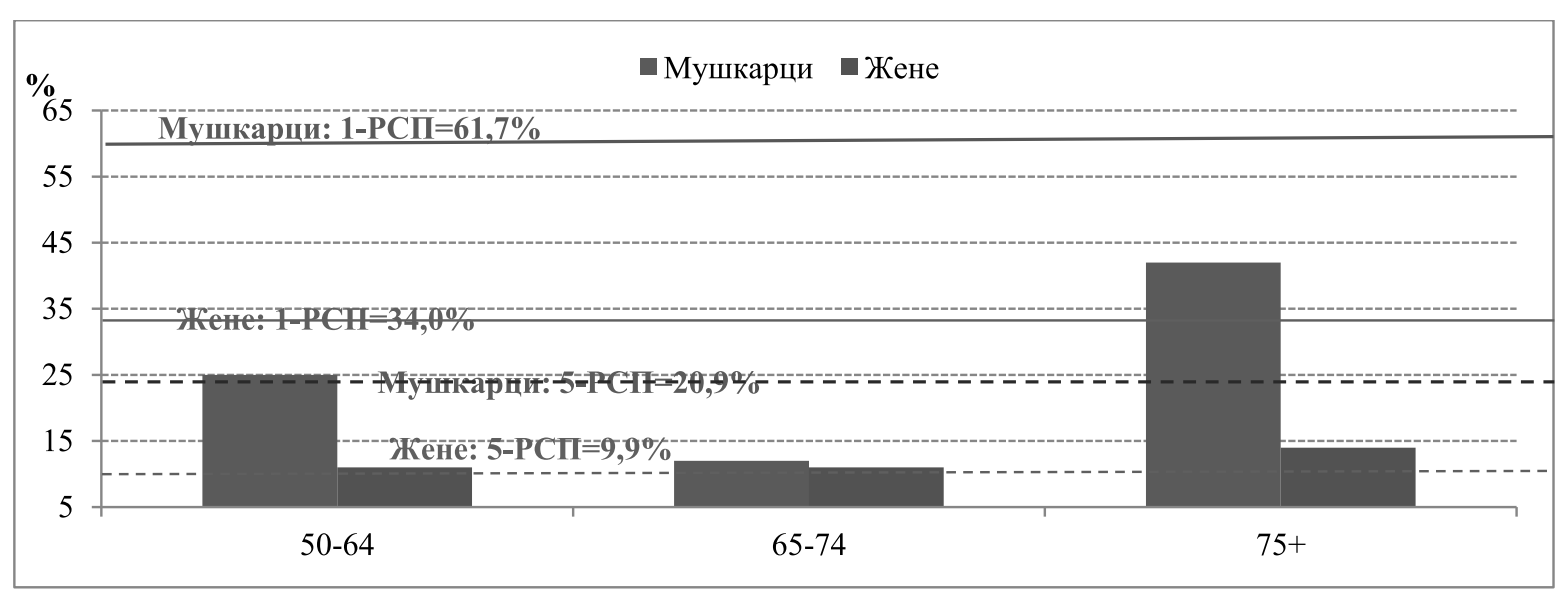

*РСП-Релативна стопа преживљавања (једногодишња 1-РСП, петогодишња 5-РПС)

Укупна релативна петогодишња стопа преживљавања код оба пола је три пута мања у односу на релативну једногодишњу стопу $(61,7 \%$ [95\% CI: 56,5-66,9\%] мушкарци; 34,0\% [95\% CI: 28,4-39,7\%] жене) преживљавања од рака плућа и душника. Код мушкараца највећа релативна петогодишња стопа преживљавања рака плућа и душника је код старијих од 75 година, док је најмање релативна петогодишња стопа преживљавања у добној скупини 65-74 године (12\%). Код жена се запажа уједначеност у релативним петогодишњим стопама преживљавања по добним скупинама које се крећу од 11\% (50-64 и 65-74 година) до 14\% (старијих од 75 година).

\section{ДИСКУСИЈА}

Инциденција и морталитет већине малигних неоплазми показује тенденцију сталног раста, а на овај раст у значајној мјери утиче пораст очекиваног трајања живота, навике и стил живота, те све присутнији канцерогени у животној и радној средини, боља дијагностика и квалитетнија евиденција ових обољења. ${ }^{(11)}$

Рак плућа и душника представља један од водећих јавноздравствених проблема становништва Републике Српске, а првенствено за особе мушког пола. Разлике у оболијевању и умирању одрака плућаи душника међу половима у Републици Српској и 
свијету треба првенствено тражити у различитој изложености мушкараца и жена фактору ризика - пушењу. Већи ризик оболијевања мушкараца од рака плућа и душника може се довести у везу са већом и дужом заступљеношћу навике пушења међу мушкарцима. Насупрот томе, жене су под мањим ризком оболијевања од рака плућа и душника због мање заступљености и каснијом појавом навике пушења. Пушење се као „друштвено прихватљива” норма понашања међу женама јавила неколико деценија касније (око 25 година) у односу на мушкарце. ${ }^{(5,12)}$ Важну улогу у порасту пушача међу женама одиграла је и дуванска индустрија, која је у слици еманциповане жене кроз рекламе презентовала пушење као „нормално” и „друштвено прихватљиво” понашање, придобијајући на тај начин жене као нове потрошаче. ${ }^{(5,13)}$

У Републици Српској, пушење као свакодневна навика више је заступљена међу мушкарцима него женама код којих је ова навика више заступљена повремено. Надаље, разлике у оболијевању од рака плућа и душника међу половима треба посматрати и с аспекта дужине пушачког стажа, као и броја дневно попушених цигарета. Просјечан број година пушачког стажа је 20,2 године (22,1 година мушкарци, 17,4 године жене). ${ }^{(6)}$ Најдужи пушачки стаж (30 година) имају становници у добној скупини изнад 65 година живота. ${ }^{(6)}$ И у погледу броја дневно попушених цигарета (20 и више цигарета) ова навика је више заступљена међу мушкарцима (свакодневним пушачима). ${ }^{(6)}$

Детерминанте које додатно повећавају ризик од настанка рака плућа и душника су број дневно попушених цигарета и дужина пушачког стажа. ${ }^{(14,15)}$ Процјене указују да у свијету пуши око 1,2 милијари људи или око 30\% одраслог становништва, a да је преваленција пушења одраслог становништва (стални и повремени пушачи) већа у земљама које према нивоу развијености припадају транзицијским и земљама у развоју. ${ }^{(16)}$
У Републици Српској стопе инциденције рака плућа и душника код мушкараца су у односу на процјене GLOBOCAN-a (2008) приближно једнаке просјеку стопа инциденције код мушкараца у регионима јужне Европе и Сјеверне Америке (49/100.000 мушкараца). ${ }^{(2)}$ Према истој процјени (GLOBOCAN, 2008) стопа инциденције рака плућа и душника код жена у Републици Српској приближно је једнака стопама инциденције у Грчкој, Шпанији и Македонији (регион јужне Европе), а за око 3 пута мања у односу на неке друге земље као што су Сједињене Америчке Државе, Данска и Канада (око 30/100.000). ${ }^{(2)}$

У односу на процјене GLOBOCAN-a (2008), стопа морталитета код мушкараца у Републици Српској је готово једнака просјечној стопи морталитета у региону јужне Европе (43/100.000 мушкараца), док је стопа морталитета код жена у Републици Српској готово једнака стопи морталитета у региону централне/источне Европе (7,9/100.000 жена) за жене. ${ }^{(2)}$

Поред пушења, као најважнијег фактора ризика за облијевања од рака плућа и душника, значајно је и пасивно пушење. Прва епидемиолошка истраживања у којима се пасивно пушење доводи у везу са раком плућа и душника објављена су 1981. године. ${ }^{(17)}$ Повезаност рака плућа и душника са пасивним пушењем, потврђује чињеница да око 15-20\% случајева рака плућа и душника настаје и код непушача, од којих се један дио њих доводи у везу са пасивним пушењем. ${ }^{(18)}$ Већи релативни ризик (RR) за оболијевање од рака плућа и душника као пасивни пушачи имају особе које живе у заједници са партнерима који су дугогодишњи пушачи. ${ }^{(19)}$ Овај ризик расте и за особе који су дуванском диму изложени на радном и јавном мјесту. ${ }^{(18,19)}$

У Републици Српској дуванском диму на радном и јавном мјесту су више изложени мушкарци у односу на жене. Дуванском диму у кући није изложено незнатно мање од половине одраслих (нешто више жене) становника. ${ }^{(6)}$ 
Највећи број обољелих и умрлих од рака плућа и душника је у добној скупини 50-74. године живота што се може довести у директну везу са највећом преваленцијом и то сталних пушача у добној скупини 35-44. године живота, као и дужином пушачког стажа (20,2 године) који расте са старошћу. ${ }^{(6)}$ Сходно дистрибуцији старосне структуре у оболијевању и умирању од рака плућа и душника, релативни ризик да се оболи, односно умре од овог рака је знатно већи прије 75. године.

Висина стопе инциденције одређује висину стопе преваленције, међутим, то није случај и са раком плућа и душника.

У Републици Српској однос између стопе преваленције и инциденције код мушкараца и жена за рак плућа и душника је 1:1. На овај однос утичу непропорционално високе стопе морталитета рака плућа и душника у односу на стопу инциденције, а што настаје као посљедица постављања дијагнозе код већине обољелих у узнапредовалој фази болести и ниске стопе излијечења од рака плућа и душника, иако је у посљедњих неколико деценија дошло до напретка у лијечењу рака плућа и душника (хируршким и терапијским методама). ${ }^{(15,20)}$ У складу са овим показатељима рак плућа и душника се може сврстати у један од најлатентнијих облика рака.

У Републици Српској укупна релативна петогодишња стопа преживљавања код мушкараца износи око $20 \%$, а код жена око $10 \%$. Релативна петогодишња стопа преживљавања од рака плућа и душника у Сједињеним Америчким Државама износи око 16\%, док се у Европи релативна петогодишња стопа преживљавања креће у интервалу од 7,9\%, до $16,5 \%{ }^{(20)}$ Процјене указују да дуже од пет година након утврђења рака плућа и душника живи мање од $10 \%$ обољелих особа. ${ }^{(18)}$

\section{ЗАКЉУЧАК И ПРИЈЕДЛОГ MJEPA}

У Републици Српској малигна обољења представљају веома значајан јавно- здравствени проблем. Једно од најчешћих малигних обољења је рак плућа и душника. Већи ризик да оболе или умру од малигног обољења имају мушкарци у односу на жене. Овај ризик нарочито долази до изражаја због веће преваленције пушења, односно веће преваленције сталних пушача међу мушкарцима. Највећи број обољелих и умрлих мушкараца и жена је у добној скупини 50-74 године живота. Овај ризик се може довести и у везу са детерминантама пушења - дужина пушачког стажа и број дневно попушених цигарета које повећавају ризик оболијевања, односно умирања од рака плућа и душника и доминантније су изражене код мушкараца. И поред већег ризика да оболе или умру од рака плућа и душника, мушкарци имају за око два пута већу укупну релативну (око $20 \%$ ) петогодишњу стопу преживљавања у односу на жене.

Република Српска је у борби против употребе дувана предузела низ мјера доношењем стратешких докумената, те законских и подзаконских аката за које постоје поуздани докази да њихова примјена смањује ризик оболијевања и умирања од рака плућа и душника, те других хроничних незаразних болести које настају као посљедица пушења. Предузимање мјера у борби против пушења подрзумијева интегрисани приступ различитих актера кроз партнерство и мултисекторску сарадњу. Како би се овим мјерама и у будућности спријечиле многе пријевремене смрти рака плућа и душника, посебно треба истаћи као најважније, континуирано спровођење здравствено васпитних мјера у предшколским, школским и здравственим установама, те радним мјестима и заједници, јер се само усвајањем здравих стилова живота и модификовањем нездравих може у значајној мјери унаприједити здравље становништва и превенирати водеће болести и рак плућа и душника. 


\section{ЛИТЕРАТУРА}

1. Thun MJ, Henley SJ. Tobacco. In: Schottenfeld D, Fraumeni JF. Jr, eds., Cancer Epidemiology and Prevention, 3rd ed., New York, Oxford University Press, 2006; 217.

2. Ferlay J, Shin HR, Forman D, Mathers C, Parkin DM. GLOBOCAN 2008 V2.0. Cancer Incidence and Mortality Worldwide. IACR Cancer Base No.10 International Agency for Research on Cancer, Lyon, France, 2010. Available at: <URL:http:// globocan.iarc.fr.> Accessed on July 6, 2012.

3. Eriksen M, Mackay J, Schluger N, Gomeshtopek FI, Drope J. The Tobacco Atlas. $5^{\text {th }}$ ed. Atlanta GA: American Cancer Society, New York, NY. World Lung Foundation, 2015. Available at: www. TobaccoAtlas.org, Acessed on July 20, 2016.

4. World Health Organization (WHO). WHO Report of the Global Tobacco Epidemiology: The MPOWER package, Geneva, World Health Organization, 2008.

5. Bray FI, Weiderpass E. Lung Cancer Mortality Trends in 36 European Countries: Secular Trends and Birth Cohort Patterns by Sex and Region 1970-2007, International Journal of Cancer (IJC), 2010; 126: 1454 1466.

6. Министарство здравља и социјалне заштите Републике Српске. Пушење. У: Истраживање здравља становништва Републике Српске, 2011.

7. Предсједништво Босне и Херцеговине.

Одлука о ратификацији Оквирне конвенције Свјетске здравствене организације, 54. сједница, 17. март 2009., Доступно на http://www. predsjednistvobih.ba/zaklj/sjed/default. aspx?id=34373\&langTag=bs-BA. 09. 12 . 2016.

8. ЈЗУ Институт за јавно здравство. Бања Лука, Република Српска. Регистар малигних неоплазми Републике Српске, основан 2001. године.
9. Doll R, Payune P, Waterhouse JAH, eds. Cancer Incidence in Five Continents. Vol I. Geneva: Union International Contre le Cancer, 1966.

10. Ferlay J, Bray F., Pisani P. Parkin DM, eds. GLOBOCAN 2002. Cancer Incidence, Mortality and Prevalence Worldwide, Lyon, France, IARC Press, 2004.

11. Јаковљевић Ђ, Ђокић Д, Павловић М, Зелен Б, Сенте Р. Здравствено стање становништва, здравствене потребе и коришћење здравствене заштите, Институт за заштиту здравља Србије „Др Милан Јовановић Батут", Београд, Завод за заштиту здравља Суботица, 1999.

12. Jemal AM, Garcia M, Ward E, Thun MJ. Section 2: Global Cancer Incidence (Surveillance, Epidemiology, and End Results Database), In: Epidemiology of Cancer, In: DeVita V.T. Jr, Lawrence T., Rosenberg S.A. Cancer Principles and Practice of Oncology, $8^{\text {th }}$ ed., Philadelphia, Lippincott Williams and Wilkins, 2008.

13. Ernster V, Kaufman N, Nichter M, Samet J, Yoon SY. Women and Tobacco: Moving from Policy to Action. Bulletin of the World Health Organization, 2000; 78: 891-901.

14. International Agency for Research on Cancer. Tobacco Smoke and Involuntary Smoking, Monographs on the Evaluation of Carcinogenic Risk to Humans, Lyon, France, 2004; vol. 83: 53.

15. National Comprehensive Cancer Network (NCCC). NCCC Clinical Practice Guidelines in Oncology (NCCC Guidelines Version 2. 2016), Lung Cancer Screening, Fort Washington, PA: NCCC, 2016.

Available at http://www.NCCC.org/patients, Accessed on July 27, 2016

16. Mackay J, Eriksen M. Tobacco Atlas, Geneva, World Health Organization, 2002.

17. Garfinkel L. Time Trends in Lung Cancer Mortality among Nonsmokers and a Note of Passive Smoking. Journal of the 
National Cancer Institute, 1981; 66: 10611066.

18. Tobias J, Hochhauser D. Tumors of the Lung and Mediastinum. In: Cancer and its Management, $6^{\text {th }}$ Edition, London, 2010.

19. International Agency for Research on Cancer. Tobacco Smoke and Involuntary
Smoking. Monographs on the Evaluation of Carcinogenic Risk to Humans, Lyon, France, 2004; vol. 83.

20. American Cancer Society. Global Cancer Facts and Figures. $2^{\text {nd }}$ ed, Atlanta, American Cancer Society, 2011.

Контакт: Мр сц. Даријана Антонић, Центар за здравствени менаџмент, ЈЗУ Институт за јавно здравство, Република Српска, Бања Лука. 